\title{
QUESTIONING GLOBAL CITIZENSHIP EDUCATION IN THE INTERNATIONALIZATION AGENDA
}

\author{
GABRIELA FREIRE OLIVEIRA PICCIN \\ Instituto Federal do Espírito Santo \\ KYRIA REBECA FINARDI \\ Universidade Federal do Espírito Santo
}

\begin{abstract}
The present paper provides a reflection on global citizenship education (GCE) in the internationalization agenda. With that aim, the internationalization of higher education (IHE) is discussed from a critical perspective, mainly informed by postcolonial and decolonial studies. More specifically, the paper addresses GCE issues related to criticisms that have been raised against it in terms of (1) its different educational approaches, (2) its cosmopolitan bias with its (3) ideological frame of the so-called "global citizen". Some alternatives to mainstream approaches to GCE and IHE are offered in the conclusion, based on the contributions of Stein (2017), Andreotti (2015) and Fiedler (2007), who advocate for the otherwise approach and/or postcolonial learning spaces.
\end{abstract}

Keywords: global citizenship education; critical internationalization; global citizenship otherwise; postcolonial learning spaces 


\section{Introduction}

Who speaks? For what and to whom?...The histories, traditions, societies, texts of 'others' are seen either as responses to Western initiatives - and therefore passive, dependent - or as domains of culture that belong mainly to 'native' elites. (Said, 1989, p. 212)

Said's questions and reflections can represent an invitation to think about the desirable citizen aimed by global citizenship education (GCE) and therefore by some internationalization programs, since the desirable citizen aimed by GCE can be found in the objectives and practices of internationalization programs (Khoo, 2014; Stein, 2017) In other words, GCE has become a goal of the Internationalization of Higher Education (IHE). Internationalization is seen by some as an effective means of developing global citizens (Gacel-Ávila, 2005; Braskamp, 2008) though the "product" of such GCE is arguably a member of Western elites (Jorgeson, 2010) mostly guided by imperialist motivations of saving/colonizing the Other (Andreotti, 2014). In this context, the Other, the one who is racialized/Indigenous, is often seen as inferior to the Self ${ }^{1}$ according to 'universal' (i.e. European/Western) values of humanity (Stein, 2017). Because of this universal outlook, many authors see GCE as a contested conception (e.g. Jorgenson, 2010; Khoo, 2014; Andreotti, 2014) which can be detected in and have an intersection with different purposes and actions of higher education (Khoo, 2014), especially in the form of contemporary IHE.

Although the development of a global citizenship is often cited as a goal of IHE, the term itself lacks research on its epistemological and ontological underpinnings (Stein, 2017). Jorgenson (2010) explains that though the basis of GCE has existed for many years in higher education programs in the form of "global education", "peace education" and "volunteer and study abroad", more recently, there seems to be a trend to respond to concepts and issues of citizenship from a global perspective (p. 26).

However, postcolonial critiques question the universalist discourse of GCE in the grounds that it does not only mask privilege and certain conformity (Khoo, 2014), but also serves the production of insiders and outsiders (Jefferess, 2008). One implication of that critique is that not everyone can be a global citizen. In the same line and as put forward by Vavrus and Pekol (2015), globalization (and we could add, IHE) does not benefit all nor does it benefit some in the same ways.

This paper offers a reflection on the GCE aimed by contemporary internationalization discourse as highlighted in IHE agendas. For doing so, we first provide a critical perspective of

\footnotetext{
${ }^{1}$ It is important to mention that the categories Self and Other, as well as Global North and Global South, are not thought from a binary perspective in this text. Instead of seeking some sort of "essence" in each of these categories, we agree with Hall (1997) that "'difference' matters because it is essential to meaning: without it, meaning could not exist" (p. 234). We understand that such difference is constructed upon discursive structures (as the permanent use of stereotypes) which meet the interests of power and colonialism. Hall also highlights that binary oppositions tend to be unneutral, what Derrida (cited in Hall, 1997, p. 235) would see as two poles: one as the dominant one, while the other pole includes the other within its field of operations.
} 
IHE from a postcolonial view (e.g. Finardi, 2019). Then, we discuss some aspects of GCE related to the maintenance of coloniality and imperialism. We argue that GCE in the IHE agendas contributes to maintain the status quo of colonialism. Last but not least and by way of conclusion, we highlight some alternatives to the hegemonic patterns, i.e. the potential colonial approaches to GCE, such as suggested by theorists for a "global citizenship education otherwise" (Andreotti, 2015; Stein, 2017) in postcolonial learning spaces (Fiedler, 2007). We believe that such alternatives to the mainstream GCE approaches might help the dialogue between the Global North and the Global South.

\section{Critical internationalization}

Some of the effects of globalization on education are evidenced in the expansion of internationalization and transnationalization of higher education. Bernheim (2018) distinguishes these two processes by linking the former to an academic motivation for academic international cooperation with an emphasis on horizontal and supportive relations while the process of transnationalization would be linked to an economic agenda and the view of higher education as a service or commodity, precisely what de Sousa Santos (2018) warns us against and what we want to challenge. Some of the criticism raised against contemporary Internationalization of Higher Education (IHE) is actually directed at what Bernheim (2018) refers to as transnationalization. Nevertheless, because an analysis of this distinction is outside the scope of this paper, we will adopt the term IHE to refer to both processes though we acknowledge Bernheim's distinction.

The view of education as 'colonization of the mind' is addressed in this paper by the adoption of a postcolonial approach for the unlearning of colonial ideologies and as a possibility of dialogue with the excluded "Other" of Western civilization. By doing so and in line with Andreotti (2011), we assume the potential of postcolonial theory to disrupt parochialisms to prompt significant shifts in thinking and practice in education in general and particularly in global citizenship education (GCE), in our case through internationalization actions.

Another assumption of this paper is that postcolonial theory may enable a reflection upon pedagogical processes present in the process of IHE, defined as the integration of an international, intercultural and global dimension in the offer of education, research and services of higher education institutions (Knight, 2003), and in the education for global citizenship, thus leading to a disenchantment with the epistemic privilege of modernity (Mignolo, 2002) that informs part of the view of IHE.

We assume an ecology of knowledges and the potential of postcolonial theory to engage with the voices in the other side of Sousa Santos' abyssal lines whereby some knowledges are visible by making other knowledges invisible, thus producing what Sousa Santos (2018) calls the end of the cognitive empire with the coming of age of epistemologies of the South with their visibility of the knowledges produced in the other side of the abyssal lines. Based on that assumption, we propose to look at the role of higher education institutions in general and the process of IHE and GCE in particular as an arena for this reflection. 
The process of IHE, sometimes seen as a synonym to GCE, has positive and negative impacts that affect countries and regions differently, yielding more benefits to the countries/institutions of the so-called Global North ${ }^{2}$ (Sousa Santos, 2011) and in the Northern Hemisphere (Vavrus \& Pekol, 2015) than to those in the Global South such as countries in Latin America and the Caribbean (Meneghel, Camargo, \& Speller, 2018).

In the preface of the book English in the South, Menezes de Souza (2019) reminds us of the distinction made by Marginson $(2007 ; 2010)$ between globalization as interconnectedness on a planetary scale and internationalization as cross-border mobility tracing back the origin of these issues to colonization and imperialism. Still according to Menezes de Souza (2019), postcolonial theory sees the resistance and opposition to previous colonial inequities occurring more effectively not by merely challenging what was previously said but instead by opening spaces for new voices to be heard. This is precisely what we intend to do in this paper.

This means that more than changing what/how something was said, it is important to hear voices from more loci of enunciation since it is where one is speaking from that becomes significant. In that sense, denounced by Menezes de Souza (2019), the latter occurs within a hegemonic process of globalization that establishes inequities among knowledges, cultures and languages in relation to other non-hegemonic knowledges, cultures and languages.

Sousa Santos (2010) denounces an institutional crisis in the realm of higher education whereby the notion of hegemony and legitimacy of higher education is questioned. Menezes de Souza (2019) further explains that the crisis of hegemony is a challenge to the traditional role of the university as the locus of production of knowledge and represents a demand for this to be substituted by the production of instrumental knowledge. Moreover, the need of universities of the South to emulate and promote links often resulting in subservience to universities of the North may result in a non-critical convergence of these two conflicting demands: universities in the South become locally hegemonic by functioning as non-hegemonic in relation to a foreign hegemonic institution in the North. This non-critical convergence is often seen as a local solution for the local crisis of hegemony of many higher education institutions in the South, such as those in Brazil (e.g. Piccin \& Finardi, 2019).

When this happens, universities of the South are positioned as consumers rather than as producers of knowledge. In regards to the crisis of legitimacy, universities of the North solve their local problem of legitimacy by extending their recruitment of fee-paying elite international students, whereas universities of the South, undergoing a similar crisis of legitimacy and access, may not be able to solve their local problem by extending access to the number of incoming international students on the same scale. Indeed, according to Lima and Maranhão (2009), referring to the process of IHE in universities of the South, the aforementioned authors claim that the IHE in Brazil follows a passive model precisely because it is not able to attract international students as universities in the North do.

The difference in models, approaches and benefits yielded by IHE points to the need to

\footnotetext{
2 The terms "Global North" and "Global South" are used in this paper as Sousa Santos (2011) refers to epistemological North and South, not necessarily geographic.
} 
see this process not as a solution to the crises of hegemony and legitimacy, but rather as a critical educational proposal for non-hegemonic, bottom-up globalization which welcomes the diversity of an ecology of knowledges in what Sousa Santos refers to as non-hegemonic cosmopolitanism. Indeed, as will be discussed in the ensuing section, one of the aims of this paper is to create a space for the reflection on possibilities of non-hegemonic, non-universalist and non-naive cosmopolitanism and GCE/IHE, referred to some as critical IHE (Finardi, 2019).

\section{Global Citizenship Education (GCE)}

According to Sousa Santos (2018, p. vii), we live in a period in which social inequality and discrimination are becoming politically acceptable. In this scenario, the discourse of responding to "global problems" through education has led to the imperative of "global responsibility" which affects educational theory and practice (Pashby, 2014). In order to decrease global problems, defenders of international education, such as some practices of global citizenship education (GCE), claim it to be a "remedy for widespread cross-cultural misunderstanding, prejudice, global ignorance, and failed international policy" (Zemach-Bersin, 2007, p. 17). However, this type of education might reinforce colonialist discourses of essentialization and exclusion expressed in forms of identity formation/reinforcement or processes of identification (Jorgenson, 2010).

In this section, we address global citizenship discourses in internationalization from three perspectives: (1) the approaches to global citizenship education (GCE), based on Stein's four global citizenship positions (2017); (2) the original aims of cosmopolitanism together with current critiques, mainly in relation to GCE; and (3) the ideological "who", i.e. the subject aimed by GCE. Further, we move on to reflect about possible alternatives to those discursive practices that have been maintaining the status quo in the area of GCE/IHE.

\subsection{Different approaches to global citizenship education: Sharon Stein's contributions}

As an institutional goal of Internationalization of Higher Education (IHE) (Khoo, 2014; Stein, 2017), global citizenship lacks a further discussion on its conceptions and groundings. This gap in the literature is perceived by Sharon Stein (2017) who analyzes global citizenship discourses. She claims them to be more "versatile, flexible and open to resignification than notions of national citizenship" (p. 174) and maps those discourses in a social cartography of four global citizenship positions, namely, the: (1) entrepreneurial, (2) liberal humanist, (3) antioppressive and (4) otherwise. It is important to mention that the first two positions are considered by the author as the mainstream approaches to global citizenship, and they are "difficult to disentangle, as the line between them is blurred in the different forms of capital (material, moral, cultural) that are accumulated by the global citizens they imagine" (Stein, 2017, p. 187).

Considering the potential coloniality of each position, the author asks each of the four positions the following questions: "what are the frames of reference within which global citizenship is conceptualized? And who inhabits the position of the global citizen, and who does not?" (Stein, 2017, p. 177). 
So, in the first position, the entrepreneurial position, Stein (2017) explains that global citizenship is often conceptualized in terms of students developing financial acuity and human capital so they can become more competitive in the global market. That global citizenship position is based on neoliberal ideas of individuals taking responsibilities and risks that once belonged to institutions and governments. Furthermore, it claims that every person - from the Global North or South - should become an autonomous entrepreneur whose accumulated capital and efforts will benefit both themselves and their countries. The problem pointed by Stein (2017) is that such position puts everyone as "equally morally obliged to make utility-maximizing choices in all areas of their life, and suggests that one's ability to succeed in this is unaffected by one's raced, gendered, and classed social positions" (p. 179). Another problem refers to the kind of extractive relations developed between the desirable global citizens and their target impoverished communities. The latter are expected to provide economic value to the former's ability to reproduce themselves and their wealth. Stein (2017) identifies the colonialist discourse and ideology in this first global citizenship position once it excludes the Other, the South, who/which is not considered to be a global citizen.

The second global citizenship position presented by Stein (2017) is that of the liberal humanist position, whose premises take for granted that humanity shares universal (i.e. Western) knowledge, values and experiences. It also assumes that difference can be overcome and the Other can be understood and accessible. In this position, the Other is seen as someone to be helped by/through the benevolent intervention of global citizens, usually Western elite (or middle-class) white subjects. One of the problems is that when students understand themselves as benevolent actors granting knowledge, humanity, resources, or rights to those they perceive to lack them, and leading the way toward universal human evolution, they simultaneously affirm the supremacy of their own knowledge and values, and absolve themselves of any complicity in harm. (Stein, 2017, p. 185)

Although the anti-oppressive position does not receive as much recognition and material support as the two first positions in the past, Stein (2017) argues that it has been receiving more attention from a growing number of scholars and students. This position criticizes the first two approaches for their depoliticized and ahistorical discourses that tend to reproduce inequalities inherited by colonialism. The anti-oppressive position frequently questions the entrepreneurial one for its emphasis on the pursuit for capital accumulation, and it also interrogates the liberal humanist position for its tendency to reinforce the 'universal' (i.e. Western) knowledge (or the visible in Sousa Santos abyssal lines), values and the supposed benevolence of the imagined global citizen (Stein, 2017, p. 191). The author highlights that the anti-oppressive position also presents limitations such as "presuming that there is a 'pure' space outside of contamination by Eurocentrism” (Stein, 2017, p. 193), and, quoting Moallem (2006, cited in Stein, 2017, p. 193), that scholars and activists will lead the rest of the people. Another limitation of this third position concerns the risk of reproducing the "assumption that Self and Other are preconstituted positions that subsequently meet within a field of (uneven) relations" (Stein, 2017, p. 193). 
The last global citizenship position analyzed by Stein (2017) is the Otherwise position based on decolonial studies which criticize the Euro-supremacy and coloniality. Instead of trying to elevate the Other to a more equal position as the Self (as the other global citizenship positions attempt), running the risk of the reinforcement of those colonial categories, the Otherwise position

would invite students to engage at the edges of what is possible or knowable within the existing imperial global imaginary, and create experiences wherein they become dissatisfied with the available possibilities. It is at that space that something "otherwise" becomes possible, though is never reassured, and the risk of relapsing back into the comfortable positions and frames of reference is high. (Stein, 2017, p. 196)

This fourth position does not clearly define the goals and outcomes of being in a relation with alterity while unlearning the dominant values and stereotypes that modernity has framed. Nonetheless, Stein sees such limitation as potential once "the otherwise positions holds open the space in which previously suppressed or unimaginable possibilities might emerge" (2017 p. 198). Further, we discuss such possibilities in order to think of alternatives to the models and practices of GCE in IHE agendas.

It is important to highlight that the desirable entrepreneurial-liberal humanist individual mentioned above meets the Euro-supremacist genealogy of 'universal' humanity whose conditions of existence are found in the notion of cosmopolitanism (Stein, 2017). Stein explains that the exemplars of this type of cosmopolitanism are usually Western subjects, and that such universal view of humanity tends to disavow the Other. The author emphasizes that the "result of this deracinated, universalizing vision, even if unintended, is that through it some can be deemed less human, or at least, lesser humans, than others, thereby potentially reproducing patterns of imperial dehumanization" (Stein, 2017, p. 80). Stein also argues that those assumptions that constitute the "imagined purposes and possibilities of both entrepreneurial and liberal humanist global citizenship tend to reflect the imperial global imaginary" (Stein, 2017, p. 189). This imperial global imaginary threatens the transformative possibilities of IHE in general reproducing prejudicial ideas.

In the next subsection, we analyze the critiques on current cosmopolitanism practices in relation to GCE/internationalization.

\subsection{Cosmopolitanism: its original principles and its current discursive practices}

Cosmopolitan conceptions of global citizenship could be naïve and uncritical when they presume that everyone can be a global citizen once they live on the planet (Jorgenson, 2010). Dower (2010) considers that much of global citizenship discourses focus on the ethical cosmopolitanism that emphasizes moral standing of individuals' obligations and rights.

According to van Hooft and Vandekerckhove (2010), during the construction of national identities, the term cosmopolitanism was historically denounced as being against the love of one's country or patriotism. In its origins, the term cosmopolitan, rather than being a term of praise, was used to describe individuals who had no loyalty to the community or nation to which 
they belonged having insufficient concern for their own compatriots or ethnicities and too much interest in the lives and cultures of foreign peoples.

More recently, this concept has been used to highlight the global outlook of people who participate in the possibilities afforded by contemporary globalization with an apparent lack of local roots and as such, missing the concept of "citizenship" present in the original term, "cosmopolitan". A cosmopolitan individual is not just one who feels at home in a globalized world, traveling and enjoying the cultural products of a global market. A cosmopolitan is a citizen of the world implying a commitment and responsibility towards all peoples of the world.

Broadly conceived, cosmopolitanism refers to both ethical and political commitments to embrace the whole world refusing to prioritize local, parochial or national concerns and in that it is aligned with critical IHE views (Finardi, 2019). In a globalized world, these ethical and political responsibilities do not stop at national borders or at the boundaries of identity, whether these are religious, ethnic, linguistic, racial or traditional. Indeed, a cosmopolitan outlook differs in fundamental ways from those expressed in any form of chauvinism, nationalism, intolerance of difference or towards foreigners, racism, imperialism and ignorance of other cultures.

Instead, contemporary cosmopolitans are suspicious of nationalism, all forms of chauvinism, and even patriotism refusing to see national economic and military interests of their country as more important than universal values such as human rights, global justice and the protection of the global environment. Cosmopolitans respect basic human rights and acknowledge the moral equality of all peoples and individuals showing benevolence to all others irrespective of race, caste, nationality, religion, ethnicity or location. Yet, it is precisely this "naïve" view of equality and benevolence that we want to question here, as Andreotti (2015) argues, on the grounds that this view may reinforce rather than solve the inequalities between the Self and the Other or between the North and the South.

Cosmopolitans advocate a commitment to justice in the distribution of natural resources and wealth on a global scale. However, we question how this distribution of natural resources and wealth can be achieved without recognizing the imbalance in its distribution and this is precisely what we want to propose, that is, the creation of spaces to think about alternatives that have not been suggested by naïve cosmopolitan discourses in the realm of GCE/IHE.

Cosmopolitans refuse to give their co-nationals any priority in their concerns or responsibilities at the expense of more distant others which perhaps explains why they have earned the despise of radical nationalists. In the same vein, they have earned criticism on the grounds that viewing all human beings as equals is not helpful to make them so. Such attitudes do not arise fully formed in the hearts and minds of cosmopolitans. They need to be developed and nurtured through processes of education and reflection and that is where popular GCE/IHE enter the picture with their salvationist discourse.

Cosmopolitan discourses in GCE are also discussed by Camicia and Franklin (2014) who see some problematic issues regarding citizenship education when analyzing the curriculum in the Philippines and the United Kingdom. In their curriculum analysis, Camicia and Franklin (2014) find an interplay between neoliberal cosmopolitan and democratic cosmopolitan 
discourses. They conclude that students are being prepared to join a global community, however the meaning of global citizenship is "complicated by a tension and blending between neoliberal and critical democratic discourses" (Camicia \& Franklin, 2014, p.15). The authors explain that citizenship education is based on the idea of a citizen who is a member of local and national communities, an idea that contradicts cosmopolitan views that are universalist rather than national. Indeed, this idea is challenged by the concept of cosmopolitan citizenship and the proposal of critical approaches that harness an awareness of power relations by the suspicion of Western discourses as an attempt to transform citizenship education into imagined consensus. In this sense, education plays an important role in constructing and maintaining such consensus or as we claimed in the beginning of this paper, "colonizing minds". As denounced by Bhabha (2010), imagined consensus serves to perpetuate power relations for the domination of the Other.

\subsection{The ideological frame of the "global citizen"}

The discussion on global citizenship education (GCE) demands a deeper analysis on its main objectives, i.e. the desirable citizen/subject aimed by GCE. In this section we argue that such imagined global citizen is Western/Northern and meets colonialist and neoliberal depoliticized neoliberal discourses.

Andreotti (2014) questions whether and how global citizenship education (GCE) addresses the economic and cultural aspects of the inequalities in power relations and wealth/labor distribution in a complex world system and we believe that addressing these issues from a cosmopolitan view of IHE are also lacking. She also warns us of the dangers of a GCE that promotes a "new civilizing mission", encouraging the new (Northern) generations to project their beliefs as universal and reproduce power relations such as those of colonialism, in an attempt to save/educate/civilize the world (Andreotti, 2014, p. 22). Based on the contributions of Dobson $^{3}$ (2005; 2006 cited in Andreotti, 2014) and Spivak (1988; 1990; 2003; 2004 cited in Andreotti, 2014), Andreotti analyzes a global citizenship campaign called "Making Poverty History" and introduces the idea of soft and critical global citizenship education.

Following Dobson's assumption that the global citizen is the one who has the chance to traverse from the local to the global, and Spivak's contributions regarding the epistemic violence of colonialism, Andreotti (2014) distinguishes the soft from the critical global citizenship education. She explains that the soft type attempts to impose to the Other, namely, the Western/Northern ways of life, education, beliefs and values, reinforcing the power relations between North and South, as well as the naturalization and legitimacy of Northern supremacy over the South. On the other hand, critical global citizenship education aims at empowering

\footnotetext{
${ }^{3}$ In the book about citizenship and the environment analyzed by Andreotti (2014), Dobson (2003) contributes to the debate about how to achieve a sustainable society, which is arguably, the upmost mission of the knowledge produced in HE. He distinguishes between ecological citizenship and environmental citizenship and though he does not think that environmental citizenship is the solution to a sustainable society, he regards it as an underexplored one. He reminds us that though environmental problems do not confine themselves to the boundaries of nationstates, citizenship is most often thought of precisely in terms of those boundaries. The author goes on to question whether the language of citizenship can be enlisted beyond the state.
} 
individuals to think critically about their cultures and actions, taking ethical responsibility towards the Other, regardless of where that Other belongs to or comes from. Andreotti considers that educators should make more informed and critical decisions regarding approaches, so that they do not "run the risk of (indirectly and unintentionally) reproducing the systems of beliefs and practices that harm those they want to support" (Andreotti, 2014, p. 30).

Balarin (2014) emphasizes that the problem of GCE is not that it does not take into account the social injustice that globalization helped to reproduce. She considers that such problem is seen from a normative perspective, focusing on changing individuals' beliefs through education (Balarin, 2014, p. 48). In other words, the normative perspective focuses on individual agency instead of global social and political structures and how they affect citizenship. The author also highlights that the material reality in which marginalized people live contradict the discursive ideals of the so-called global citizen. Regarding the latter, she explains that both global citizenship and GCE discourses were developed in a context of social change, of a globalized world, which redefined the notions of boundaries of states, populations, economies, and identities. As a result of those changes, there has been pressure to promote democracy and cohesion through citizenship education in societies that have experienced social fragmentation. So, in order to respond to those new demands, the literature on GCE tend to focus on models of citizenship that could address the different (and hybrid, e.g. Mendes \& Finardi, 2018) identities that are emerging from a complex and globalized world. However, one of the great changes pointed by the author concerns the neoliberal globalization and the role of the state in this process, and therefore, the role of education:

The new forms of structural social exclusion that emerge in the context of globalisation, particularly as seen in the developing world, pose serious challenges for the promises and prospects of a new kind of global citizenship. Here it is important to highlight that destitute populations around the world are not always lacking in formal citizenship rights, on the contrary, they might be part of countries that formally grant such rights in their own constitutions and which subscribe to international agreements on human rights, the environment, etc. and which, at this formal level, might comply with the normative requirements of desired forms of citizenship....They might also attend to schools with curricula that, again at the formal level, promote the kinds of knowledge and pedagogy that are linked to a global citizenship imagination. However, in practice, that is in citizens' everyday lives, these rights and ideas are not enacted, in part because of the very weak institutions that exist in some countries, but I think also because of the weakening of the state as a mediator of social conflicts and social differences in the context of a neoliberal globalisation that generates a very individualised and fragmented imagination of citizenship. (Balarin, 2014, p. 54)

Balarin (2014, p. 54) concludes that, just like coloniality was the hidden Other of modernity, the marginal citizen is the hidden Other of global citizenship. Based on the findings of research developed in Lima - Peru, the author also argues that this marginalized hidden Other of global citizenship tends to believe in the depoliticized neoliberal discourses which defend 
individual effort over the welfare state and its social policies. So, one of the challenges posed by GCE would involve reflecting on how the de-politization of education serves to justify private service as a necessary strategy (Balarin, 2014, p. 58). It requires thinking GCE not only in terms of what kind of global citizen is aimed, but mostly in the role of education as a mediator between state and society.

Regarding the ideological aspects of GCE, Pashby (2014) analyses the "who" aimed by GCE, i.e. the "citizen" aimed by GCE, and argues that such subject is the European citizen of the liberal nation-state. According to her findings, the global citizen should work in order to promote a "liberal democratic notion of justice on a global scale by 'expanding' or 'extending' or 'adding' their sense of responsibility and obligation to others linearly through the local to national to global community" (Pashby, 2014, p. 118). Similarly to Stein (2017), Pashby (2014) also identifies humanistic discourses and colonialist assumptions in the GCE principles.

After discussing some of the main issues regarding IHE and GCE, in the next section we discuss some possibilities to those that do not attempt to reinforce Western 'universal' epistemologies and ontology. Considering that GCE has become one of the goals of the IHE (Khoo, 2014; Stein, 2017), we take into account the power relations between the Global North (as the Self) and the Global South (as the Other) to think about alternatives to the hegemonic patterns, or otherwise.

\section{Alternatives to hegemonic patterns of GCE: GCE otherwise and postcolonial learning spaces}

As we have argued so far, there are unbalanced forces in the relations between the Global North (Self) and the Global South (Other). The mainstream forms developed by IHE and GCE are rooted in the same problem, namely: the heritage of colonialism that has divided the world into unequal imaginary poles. In such imaginary, there is a dichotomic relation between those poles, represented by the so-called "dominant" Global North, and the "submissive" Global South. In the context of the IHE and particularly GCE, the latter seems to be passive, waiting for the aid of the former, which is the active part in this imagined relation (Andreotti, 2015; Stein, 2017). As Andreotti (2015) states:

I have focused my research efforts on trying to articulate how and why humanity has been divided between those who are perceived to be leading progress, development and human evolution; and those who are perceived to be lagging behind. I have recently started to articulate this problem as the result of the violent dissemination of a dominant modern/colonial global imaginary based on a single story of progress, development and human evolution that ascribes differentiated value to cultures/countries that are perceived to be behind in history and time and cultures/countries perceived to be ahead. (p. 222)

Thus, our claim in this paper is that it is not possible to address such problems inherited by colonialism through the same scopes that have reinforced it. On the other hand, we do not want to follow some educational theorists who advocate the "there is no alternative" discourse (Marginson, 2006; Pashby, 2014). As Souza Santos (2007) has already pointed out, there are 
alternative possibilities to those inherited by colonial modernity, even if the latter made them invisible through abyssal lines. We must question whether we can or cannot perceive nonhegemonic pedagogies, approaches and epistemologies. However, Andreotti (2015) highlights that exposing colonial hierarchies and dichotomies does not solve the problem.

Furthermore, Andreotti (2015) argues that this colonial modern imaginary is naturalized and defines what is considered to be intelligible. The author also explains that, for us to think of "ourselves as more knowledgeable, educated, ingenious, sanitary and evolved dispensers of rights, schooling and democracy, we have inevitably needed others who embody the opposite characteristics" (Andreotti, 2015, p. 225), as in the Self/Other or North/South divide.

So, based on the contributions of Spivak (2004, cited in Andreotti, 2015), Andreotti considers that the dominant part of this global imaginary, the Global North (Self), should first admit the complicity in the harm/impoverishment of the Other, the Global South. Secondly, it is necessary to interrupt the satisfaction with these desires of supremacy/superiority. According to Spivak (2004, cited in Andreotti, 2015), education plays an important role in such change of mentality once imparting knowledge might change people's mindsets and behavior.

On the previous section, we discussed the Otherwise global citizenship position presented by Stein (2017) who addresses some important aspects of this approach. One of those concerns the interdependence of both parts, instead of the total dependence of the Other on the Self. Another aspect of the otherwise position is the claim of unlearning the colonial categories of knowing and relating. In other words, we should abandon the colonial frames that have shaped our mindsets and relations in order to make space for relations "in ways as-yet unimaginable" (Stein, 2017, p. 199).

The attempt to think otherwise in ways as-yet unimaginable does not offer any kind of guarantees, as Stein (2017) reminds us. In line with her, we see this as potential for relating to alterity/ the difference. That last issue invites us to think the possible "as-yet to be" spaces. In the context of internationalization and GCE, we attempt to conceive such spaces based on the dialogue of Fiedler (2007) with postcolonial studies.

Fiedler (2007) argues that educators should take the risk to create a crisis in education, otherwise it is not possible to re-think nor re-create new possibilities and alternatives to the heritage of colonialism. According to the author, educational approaches such as development education and intercultural education have already "paved the way for the opening up of sites of enquiry where assumptions and perceptions can be challenged and critiqued from a global and social justice perspective" (Fiedler, 2007, p. 51). To the author, the aforementioned approaches pursue the development of critical thinking, which is crucial to engage the difference.

Thus, the history of the engagement between "us" and "them", or the "Self" and "the Other", etc. needs to be critically analyzed (Fiedler, 2007). Postcolonial theorists such as Homi Bhabha (2010) have stated that the colonial discourse is constructed on stereotypes of the Other, reinforced by translations and representations of the Other as "primitive", "inferior". Fiedler (2007, p. 54) points out that the encounter of those uneven parts, colonizer and colonized, has not been an "equal dialogue between partners but as a process in which the superiority of the 
colonizer's own culture was generated, established and reinstated over time". Fixed in representations imposed by colonialism, the colonized had to "write back" from a place of nonexistence (Fiedler, 2007).

So, the Third Space proposed by Bhabha is not simply the opportunity for the encounter of the unbalanced forces of colonizer and colonized. Rather, it is the space of hybridity, where they negotiate their difference. Fiedler (2007) defends that education should promote and create postcolonial learning spaces where "identities and difference are constantly negotiated and rewritten" (p. 56). According to the author,

such postcolonial learning spaces would facilitate a process in which the fixed nature of

Western ideas and concepts such as identity, culture, knowledge or meaning are

questioned by positive notions of hybridity and diversity. They could become 'third spaces' were all knowledge is questionable and at the same time they could be 'imaginary homelands', providing the safety of the familiar without lying about the constructiveness of such spaces. As imaginary homelands they are as real as they are constructed. (Fiedler, 2007, p. 56)

We believe that international programs/universities/curricula that involve GCE should create third/alternative spaces as postcolonial learning spaces that promote the negotiation of difference instead of its celebration. Moreover, international education must attempt to think otherwise, in as-yet to be relations, more equal, respectful and balanced, perhaps in that coming in between the origins of cosmopolitanism and current GCE/IHE practices.

\section{Conclusion}

In this paper we offered a problematization of global citizenship education (GCE) in the Internationalization of Higher Education (IHE) agenda. For doing so, we discussed IHE from a critical perspective, considering both postcolonial and decolonial analyses. We also provided a debate on some important issues regarding GCE, especially with respect to its educational approaches, cosmopolitan discourses and neoliberal ideological frames. We attempted to demonstrate how colonialism operates to maintain a global imaginary and how education plays a key role in the reinforcement of the status quo, especially regarding the maintenance of hegemonic discourses of a desirable global citizen to be achieved by IHE.

We presented some alternatives to the mainstream approaches of GCE proposed by theorists informed by postcolonial and decolonial studies. Stein (2017) defends that educators should take the risk of the otherwise approach: that means moving towards the unknown, the yetto-be relations that are unimaginable at the moment. Likewise, Andreotti (2015) considers that, in order to interrupt the colonial desires of supremacy/superiority, GCE must help people's reflection on their own satisfaction and complicity with the maintenance of the status quo. In other words, GCE should invite the Self (the Global North) to critically think about one's position of privilege in relation to the Other (the Global South). The author considers education as a potential means to change people's behavior and in that she is aligned with the cosmopolitan 
objectives that she criticizes once cosmopolitanism sees GCE as a way to change people's behavior by nurturing the virtues espoused by this framework.

Finally, in line with Fiedler (2007) we highlighted the third space proposed by Bhabha (2010) as a possible postcolonial learning space to negotiate the difference that both the Self (the colonizer) and the Other (the colonized) carry as hybrid subjects. As a provisory conclusion, we understand that IHE and GCE might help the dialogue between the Global North and the Global South. We also understand that historically the encounter of those parts has generated violence once they were/are in uneven power relations. In order to attempt to destroy such colonial structures, we believe that educators should be critically informed about the GCE approaches they intend to adopt and the consequences of their choices. Furthermore, the Self/Global North/colonizer must recognize themselves as hybrid subjects just like the Other they try to fix and colonize (Bhabha, 1996).

\section{Acknowledgements}

This study was developed within the context of the Center for Studies in International Relations as the Federal University of Espirito Santo (NERI-Ufes).

Author Kyria Rebeca Finardi would like to thank Fapes for support (Edital Fapes Universal 03/2017). 


\section{References}

Andreotti, V. O. (2011). Actionable postcolonial theory in education. New York, NY: Palgrave Macmillan. doi:10.1057/9780230337794

Andreotti, V. O. (2014). Soft versus critical global citizenship education. In S. McCloskey (Ed.), Development education in policy and practice (pp. 21-31). London: Palgrave Macmillan.

Andreotti, V. O. (2015). Global citizenship education otherwise: Pedagogical and theoretical insights. In A. A. Abdi, L. Schultz, \& T. Pillay (Eds.), Decolonizing global citizenship education (pp. 221-229). The Netherlands: Sense Publishers.

Balarin, M. (2014). Global citizenship and marginalisation: Contributions towards a political economy of global citizenship. In V. O. Andreotti (Ed.). The political economy of global citizenship education (pp. 48-59). Oxon: Routledge.

Bernheim, C. T. (2018). Los desafíos de la universidad en el Siglo XXI y la universidad del futuro. In S. M. Meneghel, M. Camargo, \& P. Speller (Eds.), De Havana a Córdoba: Duas décadas de educação superior na América Latina, (pp. 233-270). Blumenau, Brazil: Editora Nova Letra.

Bhabha, H. (1996). O terceiro espaço. Revista do Patrimônio Histórico e Artístico Nacional, 24, $35-41$.

Bhabha, H. (2010). O local da cultura. Belo Horizonte, Brazil: UFMG.

Braskamp, L. A. (2008). Developing global citizens. Journal of College and Character, 10(1), 15.

Camicia, S. P., \& Franklin, B. M. (2014). What type of global community and citizenship? Tangled discourses of neoliberalism and critical democracy in curriculum and its reform. In: V. O. Andreotti (Ed.), The political economy of global citizenship education (pp. 5-16). Oxon: Routledge.

Dobson, A. (2003). Citizenship and the environment. Oxford University Press.

Dower, N. (2010). Questioning the questioning of cosmopolitanism. In S. V. Hooft, \& W. Vandekerckhove (Eds.), Questioning cosmopolitanism (pp. 3-20). London: Springer.

Fiedler, M. (2007). Postcolonial learning spaces for global citizenship. Critical Literacy: Theories and Practices, 1(2), 50-57.

Finardi, K. R. (2019). Linguística aplicada: Da crítica à internacionalização a uma internacionalização crítica. In K. R. Finardi, R. Tilio, V. Borges, A. Dellagnelo, \& E. Ramos (Eds.), Transitando e transpondo n(a) linguística aplicada (1st. ed., Vol. 1, pp. 3351). Campinas: Pontes.

Gacel-Avila, J. (2005). The internationalisation of higher education: A paradigm for global citizenry. Journal of Studies in International Education, 9(2), 121-136.

Hall, S. (Ed.) (1997). Representation: Cultural representations and signifying practices. London; Sage Publications.

Hooft, S. V., \& Vandekerckhove, W. (2010). Introduction. In S. V. Hooft, \& W. Vandekerckhove, (Eds.), Questioning cosmopolitanism (xv - xxviii). London: Springer. 
Jefferess, D. (2008) Global citizenship and the cultural politics of benevolence. Critical Literacy: Theories and Practices. 2(1), 27-36.

Jorgenson, S. (2010). De-centering and re-visioning global citizenship education abroad programs. International Journal of Development Education and Global Learning, 3(1), 23 38.

Khoo, S. (2014). Ethical globalization or privileged internationalization? Exploring global citizenship and internationalization in Irish and Canadian universities. In V. O. Andreotti (Ed.), The political economy of global citizenship education (pp. 31-47). Oxon: Routledge.

Knight, J. (2003). Updated definition of internationalization. International higher education, $33(3), 2-3$.

Lima, M. C., \& Maranhão, C. M. S. A. (2009). O sistema de educação superior mundial: Entre a internacionalização ativa e passiva. Avaliação: Revista da Avaliação da Educação Superior, 14(3), 583-610.

Marginson, S. (2006). Engaging democratic education in the neoliberal age. Educational Theory, 56(2), 205-219.

Marginson, S. (2007). Globalisation, the "idea of a University" and its ethical regimes. Higher Education Management and Policy, 19(1), 1-15.

Marginson, S. (2010). Higher education in the global knowledge economy. Procedia-Social and Behavioral Sciences, 2(5), 6962-6980.

Mendes, A. R. M., \& Finardi, K. R. (2018). Linguistic education under revision: Globalization and English teacher education. Education Sciences, 4(1), 45-64.

Meneghel, S.M., Camargo, M., \& Speller, P. (2018). Apresentação. In S. M. Meneghel, M. Camargo, \& P. Speller (Eds.), De Havana a Córdoba: Duas décadas de educação superior na América Latina (pp. 7-17). Blumenau, Brazil: Editora Nova Letra.

Menezes de Souza, L. M. (2019). Introduction. In K. R. Finardi (Ed.), English in the South (pp. 9-24. Londrina, Brazil: Eduel

Mignolo, W. (2002). The geopolitics of knowledge and the colonial difference. The South Atlantic Quarterly, 101(1), 57-96.

Pashby, K. (2014). Cultivating global citizens: Planting new seeds or pruning the perennials? Looking for the citizen-subject in global citizenship education theory. In V. O. Andreotti (Ed). The political economy of global citizenship education (pp. 118-133). Oxon: Routledge.

Piccin, G. F. O., \& Finardi, K. R. (2019). A internacionalização a partir de diferentes LOCI de enunciação: As concepções de sujeitos praticantes do currículo profissional. Trabalhos em Linguística Aplicada, 58(1), 313-340.

Said, E. W. (1989). Representing the colonized: Anthropology's interlocutors. Critical Inquiry, 15(2), 205-225.

Sousa Santos, B. (2007). Para além do pensamento abissal: Das linhas globais a uma ecologia de saberes. Revista Crítica de Ciências Sociais, (78), 3-46. 
Sousa Santos, B. (2010). The university in the twenty-first century: Toward a democratic and emancipatory university reform. In M. W. Apple, S. J. Ball, \& L. A. Gandin (Eds.), The Routledge international handbook of the sociology of education (pp 274-282). US, Canada: Routledge. Retrievied from https://estudogeral.sib.uc.pt/bitstream/10316/44155/1/The\%20University\%20in\%20the\%2 0Twenty-first\%20Century.pdf

Sousa Santos, B. (2011). Epistemologías del sur. Utopía y Praxis Latinoamericana, 16(54), 17 39.

Sousa Santos, B. (2018). The end of the cognitive empire: The coming of age of epistemologies of the south. Durham: Duke University Press.

Stein, S. (2017). Contested imaginaries of global justice in the internationalization of higher education (Doctoral dissertation). University of British Columbia, Vancouver, BC.

Vavrus, F., \& Pekol, A. (2015). Critical internationalization: Moving from theory to practice. FIRE: Forum for International Research in Education, 2(2), 5-21. Retrieved from https://preserve.lehigh.edu/fire/vol2/iss2/2/.

Zemach-Bersin, T. (2007). Global citizenship and study abroad: It's all about US. Critical Literacy: Theories and Practices, 1(2), 16-28. 